\title{
PERAN SOSIAL HADITH DAN SIGNIFIKASI SEJARAHNYA MENURUT MUHAMMAD ASAD
}

\author{
Ahmad Nabil Amir \\ International Institute of Islamic Thought and Civilization (ISTAC-IIUM) \\ nabiller2002@gmail.com
}

\begin{abstract}
Abstrak
Makalah ini menyorot fikrah hadith Muhammad Asad (1990-1992) dan kontribusinya dalam pemahaman hadith kontemporer. Ia membincangkan kefahaman asas tentang hadith yang dirumuskan dalam karya-karyanya seperti Sahih al-Bukhari The Early Years of Islam; Islam at The Crossroads (bab "Hadith and Sunnah" dan "The Spirit of the Sunnah"); This Law of Ours and Other Essays; The Road to Mecca dan The Message of the Qur'an. Pengaruh hadith ini turut ditinjau daripada artikelnya dalam jurnal Arafat dan makalahnya yang lain terkait tema-tema hadith dan sunnah dan pemahaman serta cabarannya di abad moden, seperti tulisannya "Social and Cultural Realities of the Sunnah". Reka bentuk kajian adalah bersifat deskriptif, analitis, historis dan komparatif. Kajian cuba mengembangkan ide dan fikrah hadith yang dirumuskan Asad dari perspektifnya yang moden dan membandingkannya dengan pemikiran-pemikiran sejarah yang krusial terkait prinsip hadith yang dibawakan oleh pemikir Islam yang lain. Dapatan kajian menyimpulkan bahawa Muhammad Asad telah memberikan sumbangan yang penting dalam pemikiran hadith di abad moden dengan hasil penulisannya yang prolifik dan substantif, termasuk terjemahan dan syarahannya yang ekstensif terhadap Sahih al-Bukhari yang memuatkan komentar-komentar yang baru dan analisis sejarahnya yang mendalam terhadap kitab ini. Ia merumuskan pertentangan-pertentangan hukum dan istinbat-istinbat fuqaha dan muhaddith dalam tradisi syarah hadith yang kritis. Ia turut merespon pertikaian-pertikaian asas yang dibangkitkan oleh golongan orientalis dan intelektual yang skeptis terhadap riwayatriwayat sejarah dalam tradisi hadith.
\end{abstract}

Kata kunci: Muhammad Asad, Hadith, Sunnah, Sahih al-Bukhari

\begin{abstract}
The paper analyse the ideas of hadith (prophetic tradition) as espoused by Muhammad Asad (1990-1992) and its significance in contemporary hadith thought. It studies the essential ideas he developed in his discussion of hadith as reflected in his works such as Sahih al-Bukhari The Early Years of Islam; Islam at The Crossroads (chapter "Hadith and Sunnah" and "The Spirit of the Sunnah"); This Law of Ours and Other Essays, The Road to Mecca and The Message of the Qur'an. The influence of hadith was also deeply manifested in his "journalistic monologue" Arafat: A Monthly Critique of Muslim Thought, a periodical he founded in 1946 in Kashmir and other works that addresses significance principles and issues of hadith and essays that incorporate rising themes in contemporary ages, such as "Social and Cultural Realities of the Sunnah". The research was structured based on descriptive, analytical, historical and comparative method. It
\end{abstract}


attempts to analyse the crucial ideas of hadith principles brought forth by Asad and compared these with other critical views set forth of classical Muslim traditionists. The study concluded that Muhammad Asad had significantly contributed to the revival and development of hadith in the modern world with his profound translation and commentary of al-Bukhari's Sahih - Sahih al-Bukhari The Early Years of Islam - that extensively survey the significant tradition of hadith and its intellectual and historical manifestation over centuries. He also responded to the traditional arguments by historian and orientalists who were sceptical of the historical authenticity of hadith narrative and tradition.

Keyword: Muhammad Asad, Hadith, Sunnah, Sahih al-Bukhari

\section{Pendahuluan}

Kertas ini melihat kesan-kesan awal dari pengaruh hadith terhadap pandangan hidup Muhammad Asad dan fikrah dan kesedaran Islamiyahnya. Dalam perjuangannya mempertahankan dan mengembangkan aliran dan mazhab pemikiran moden dalam tradisi hadith ini, Asad telah membawa kesedaran yang krusial terhadap sejarah pemikiran dan tradisi intelektualnya melalui penulisan dan penafsirannya yang signifikan yang mengembangkan gagasan-gagasan yang berpengaruh tentang kekuatan fikrah dan tradisi hadith klasik sebagai yang tercantum dalam karya-karyanya seperti Sahih al-Bukhari The Early Years of Islam yang menganalisis riwayat-riwayat hadith Sahih dan kemungkinan-kemungkinan pemahamannya dalam konteks moden. Dengan aspirasi Islamnya yang dinamik dan progresif, Asad berusaha membawa dan menggariskan ajaran-ajaran dan fikrah-fikrah hadith yang signifikan yang mempertahankan idealismenya yang rasional dan dinamik dalam penafsiran syariat. Ia cuba mengangkat kekuatannya sebagai asas hukum dan esensi terpenting dari ajaranajaran Islam yang asli yang dikembangkan dalam sunnah-sunnah dan praktik-praktik hukum Islam yang terawal.

\section{Latar Kehidupan}

Muhammad Asad dilahirkan sebagai Leopold Weiss pada 12 Julai 1900 di Lemberg, saat itu termasuk bahagian dari kekaisaran Austria-Hungaria, dalam lingkungan keluarga Yahudi ortodoks. Beliau merupakan cucu kepada seorang Rabbi ortodoks di Czernowitz, kota di selatan Ukraine di daerah Bukowina, Austria. Asad merupakan seorang wartawan, pengembara, pengarang, ahli bahasa, ahli teori politik, diplomat dan cendekiawan Islam yang terkenal. Ia termasuk salah seorang Muslim Eropah yang paling berpengaruh pada kurun ke-20.

Menjelang usia tiga belas tahun, Weiss muda berhasil menguasai dengan fasih bahasa Hebrew dan Aramaic, selain dari bahasa asalnya Jerman dan Polish. Menjelang pertengahan dua puluhannya, beliau dapat membaca dan menulis dalam bahasa Inggeris, Perancis, Parsi dan Arab. Beliau mengikuti kerjaya kewartawanan, dan mengembara ke Timur Tengah sebagai koresponden untuk Frankfurter Zeitung di German. Di negara mandatori Palestin, Weiss terlibat dalam perbantahan dan 
argumentasi dengan pemimpin Zionis sebagai Chaim Weizmann, menyuarakan keberatannya tentang sebagian aspek dari Gerakan Zionis. Setelah menjelajah menyeberangi Dunia Arab sebagai wartawan, beliau memeluk Islam pada tahun 1926 dan memilih bagi dirinya nama Islam "Muhammad Asad" - Asad merupakan terjemahan Arab dari nama asalnya Leo (Lion) [singa]. Ia meneruskan kembaranya dan bekerja di dunia Islam, termasuk Arab Saudi, Iran, Jordan, Utara Afrika, dan Pakistan.

Pada permulaan tahun 1927 Asad menetap di kedua kota suci Makkah dan Madinah, sebagai tamu diraja pemerintah Saudi di Hijaz. Di Arab Saudi, beliau menghabiskan waktunya dengan puak Badui dan bersyarikat dengan Ibn Saud - pengasas Arab Saudi yang moden. Pertemuan dengan Putera Faysal di perpustakaan besar Masjidil Haram menemukannya dengan Raja Abdul Aziz al-Sa'ud, yang merupakan pengasas Arab Saudi yang moden. Artikel-artikelnya yang diterbitkan dalam surat khabar yang berpengaruh di Eropah menceritakan pengalamannya dalam kehidupan masyarakat Arab di padang pasir Najd dan Hijaz, mempelajari sejarah dan aspirasi politik dan cita-cita Islam yang diperjuangkan dan harapannya terhadap pembaikan dan dakwah dan keyakinannya terhadap struktur politik yang diasaskan Ibnu Saud telah mencetuskan penghargaan yang mendalam Raja Abdul Aziz terhadap daya pemikiran dan kepintaran Asad.

Asad meninggalkan Tanah Arab dan menuju ke India pada 1932 di mana beliau bertemu dengan filasuf dan pujangga Islam yang terkenal Allamah Muhammad Iqbal (1876-1938), ahli falsafah dan pujangga Islam yang terkenal. Iqbal membujuknya untuk mengurung niatnya untuk menjelajah ke arah Timur dan "membantu menjelaskan premis intelektual bagi masa depan negara Islam".

Di India, Iqbal memperkenalkan Asad kepada aktivis dan tokoh Islam di India seperti Chaudhry Niaz Ali Khan, pengasas Dar ul Islam di Pathankot, India dan Jauharabad, Pakistan. Beliau turut memintanya untuk mengajar studi Islam kepada anak-anak muda di Islamia College Lahore. Iqbal banyak mendiskusikan tentang Asad dalam warkahnya yang ditulis kepada Syed Nazeer Niazi pada 1934 (catatan surat-suratnya antara JunOktober 1934 yang dimuat dalam Kulliyat e Makateeb e Iqbal, jil. 3, hh. 529 ke atas). Iqbal turut mengusulkan Asad untuk menterjemahkan Sahīh al-Bukhārī ke dalam bahasa Inggeris, yang diusahakannya dengan positif pada musim panas 1934 di Kashmir, dan Srinagar dan sempat menerbitkan dua bab terawal dari terjemahannya. Cetusan yang diilhamkan Iqbal telah menghasilkan karya penting-nya Sahīh al-Bukhārī: The Early Years of Islam, sebagai satu-satunya syarah dan komentar yang ekstensif ke atas Kitāb Sahīh yang pernah dihasilkan dalam bahasa Inggeris, yang jauh mengatasi kitab-kitab terjemahan lain dengan pandangan-pandangan modennya, istinbat-istinbat fiqh, dan tafsiran-tafsiran moral dan spiritualnya yang berbobot dan meyakinkan.

Asad juga menghabiskan lima tahun dalam tahanan Pemerintah British ketika pecahnya Perang Dunia Kedua. Pada 14 Ogos 1947, Asad mendapat kewarganegaraan Pakistan dan kemudian berkhidmat dalam sejumlah posisi birokratik dan diplomatik termasuk Pengarah Department of Islamic Reconstruction, Timbalan Setiausaha (Bahagian Timur Tengah) di Kementerian Luar Pakistan dan Wakil Pakistan ke Pertubuhan BangsaBangsa Bersatu. Asad dilantik untuk mengepalai Department of Islamic Reconstruction, Pakistan dan terlibat dalam meneliti dan merumuskan konsep-konsep ideologi tentang 
organisasi politik dan kenegaraan Islam; dan merangka konstitusi dasar dari visi yang diilhamkan oleh Iqbal. Kerangka teoretis tentang pandangan politik dan konsepsi yang dirangkanya ini dilakarkan dalam tulisannya Islamic Constitution-Making yang diterbitkan pada bulan Mac 1948.

Pada 1949, beliau meninggalkan tugas dalaman politik untuk menyertai kementerian luar sebagai ketua Bahagian Timur Tengah. Setelah 20 tahun berada di benua kecil, pada awal 1952, Asad berhijrah ke New York sebagai duta besar Pakistan ke Pertubuhan Bangsa-Bangsa Bersatu. Di Barat, Asad menonjol sebagai pengarang dengan karya autobiorafinya yang terlaris, The Road to Mecca. Pada 1961 Asad menerbitkan bukunya The Principles of State and Government in Islam (University of California Press) yang membahas tentang persoalan negara Islam dan hubungannya dengan tatanan sosial dan politik masyarakat dan tuntutan spiritual dan agamanya.

Selanjutnya, setelah tujuh belas tahun membuat penyelidikan ilmiah, beliau menerbitkan magnum opusnya, The Message of the Qur'an - terjemahan dan komentar Inggeris terhadap al-Qur'an. Karya ini, bersama dengan terjemahan Pickthall dan Yusuf Ali, dianggap salah satu terjemahan yang paling berpengaruh di abad moden. Penganjur yang ghairah terhadap ijtihad dan rasionaliti dalam menafsirkan teks-teks agama, beliau mendedikasikan karyanya "Untuk Kaum Yang Berfikir". Pada 2008, pintu masuk jalan ke Pejabat UN di Vienna dinamakan sebagai Muhammad Asad Platz sebagai memperingati usahanya sebagai "pembina-jembatan antara agama". Asad digambarkan oleh pencatat biografinya sebagai "Anugerah Eropah kepada Islam" dan "Pengantara antara Islam dengan Barat". Pada 1982 dari Tangier beliau berhijrah ke Sintra, di luar Lisbon. Kemudiannya menetap di Mijas, di daerah Costa del Sol, selatan Sepanyol di mana beliau wafat pada 20 Februari 1992, dalam usia 91 tahun, dan dikuburkan di tapak pemakaman yang sederhana di Gibraltar. Antara karangannya termasuklah Islam at the Crossroads, The Road to Mecca, The Unromantic Orient, The Spirit of Islam, HomeComing of the Heart, This Law of Ours and Other Essays dan magnum opusnya, The Message of the Qur'ān.

\section{Telaah Asad ke atas Hadith dan Sejarahnya}

Perhatian Asad yang mendalam terhadap hadith sebenarnya mulai tumbuh sewaktu beliau berkelana selama lima tahun di Madinah. Ketika mempelajari ilmu hadith di Masjid Nabawi, suasana yang tenteram itu menimbulkan semangat Islam yang luar biasa kepadanya. Ia menjadi impian Asad untuk melahirkan pemahaman yang baru terhadap teks yang berusia ribuan tahun yang dapat memberikan penghargaan langsung terhadap semangat dan ajaran Islam yang sebenar. Kesan ini dihimbau dalam bukunya Islam at the Crossoads: "Saya tinggal lebih lima tahun di Hejaz dan Najd, kebanyakan di Madinah, supaya saya dapat mengalami sesuatu dari alam sekitar yang asli di mana agama ini dikhotbahkan oleh Nabi (saw) berbangsa Arab itu." (Muhammad Asad, 1983)

Kekuatan ini yang membangkitkan keazamannya untuk mengupas Sahīh al-Bukhārī sepanjang berkelana di Madinah selama lima tahun, mempelajari ilmu berkaitan 'ulūm 
al-hadith itu. Ia ingin melahirkan pandangan-pandangan moden dengan komentarkomentar yang cukup baru ke atas kitab Sahih al-Bukhārī yang dapat menghidupkan kesedaran dan pemahamannya yang sebenar. Ia ingin memulihkan dan membawa kefahaman yang ideal terhadap pandangan hidup Islam dan ajaran-ajarannya yang asal yang dikhutbahkan oleh Nabi (saw) dan semangatnya yang asli yang digarap dan dilacak dari babak-babak sejarah dari ribuan tahun yang lampau. Kesan ini dirumuskan dalam pengantarnya kepada kitab Sahih al-Bukhārī: The Early Years of Islam (1938) melakarkan latar tentang syarahnya ke atas kitab Sahih:

"Ide untuk menterjemahkan kitab Sahīh ke dalam bahasa Inggeris - tugas yang belum pernah dicuba sebelumnya - tercetus sewaktu saya berkelana selama lima tahun di Madinah, ketika mempelajari ilmu hadith di Masjid Nabawi. Dalam iklim yang tenteram itu, keperluan untuk menemukan sekali lagi hubungan langsung dengan semangat Islam yang asli hadir dengan kekuatan yang luar biasa kepada saya. Sesungguhnya adalah tidak memadai, saya sedar, untuk mengetahui apa orang yang hebat itu dan ini fikirkan tentang hal-hal yang Islamik; maka adalah tidak memadai untuk hidup di bawah bayangan pemikiran yang telah difikirkan pada zaman yang begitu jauh dari kita yang hampir tiada persamaan dengan kehidupan kita sekarang. Apa yang sangat mendesak yang kita perlukan hari ini adalah kefahaman baru dan penghargaan langsung terhadap ajaran Islam yang sebenar. Untuk mencapai ini kita harus sekali lagi menjadikan riil suara Nabi Islam - begitu riil, seakan-akan Baginda berbicara langsung dengan kita dan untuk kita: dan di dalam hadithlah suara Baginda dapat didengar dengan paling jelas sekali."

Dalam membela aspirasi dan cita-cita Islam ini, ia banyak diyakinkan dari pembacaannya terhadap kitab-kitab hadith dan karya-karya besar Islam yang membawa pandangan hidup Islam yang sebenar. Pengkajian dan pembelajarannya di kota Makkah dan Madinah itu telah membawanya kepada satu keyakinan yang pasti, bahawa Islam, sebagai suatu fenomena sosial dan spiritual, dalam segala kepincangan akibat kekurangan yang ada pada sekian Muslim, masih merupakan kekuatan dan tenaga penggerak yang luar biasa yang pernah dirasai manusia. Bermula dari situlah hingga ke akhir hayatnya, minatnya berkisar disekitar masalah yang perlu dihadapi dalam menghidupkan semula Islam.

\section{Hadith dan Formulasi Hukum}

Dalam merumuskan prinsip-prinsip hukum yang harus ditegakkan dalam negara Islam, Asad mencerakinkan gagasan-gagasan awalnya dalam draf yang dirangkanya pada 1947 bertajuk Islamic Constitution Making (yang diterbitkan di Lahore dengan biaya pemerintah - dalam bahasa Urdu dan Inggeris pada 1948) yang menyediakan rencana asal dari dustur negara Pakistan. Asad ketika itu mengepalai Department of Islamic Reconstruction yang ditugaskan oleh pemerintah Pakistan untuk merangka dan menyusun suatu konstruksi asas bagi perlembagaan atau dustur yang bakal diberlakukan di negara yang baru didirikan. Asad menggariskan dasar dan prinsip asas yang dirumuskan dari nas dan tradisi al-Qur'an dan Sunnah, di mana beliau menggariskan dua batas penentu, i.e., dalam negara Islam kedaulatan yang sebenar 
terletak pada Tuhan dan bahawa orang-orang beriman harus menyelenggarakan semua urusan menyangkut dengan negara dan masyarakat melalui musyawarah. Gagasangagasan awal ini dibangunkan di atas nas-nas yang jelas yang diilhamkan dari hadithhadith sahih dalam kitab al-Sahihayn - Sahih al-Bukhari dan Sahih Muslim - Sunan alTirmidhi, Sunan Abu Daud, Sunan al-Nasa'i, Sunan Ibn Majah, Al-Muwatta', Musnad Ahmad, Sunan al-Bayhaqi dan lain-lain.

Dalam menyusun asas-asas intelektual dan kemasyarakatan yang akan menjadi landasan bangunan negara Islam Pakistan ini, Asad telah merumuskannya dari 70 hadith yang sahih, yang darjat kesahihannya paling tinggi yang tidak memungkinkan celah-celah - yang secara teknikalnya- dapat dipertikaikan. Ia turut melihat pada konteks dan asbabnya sesuatu hadith dikeluarkan. Nas-nas yang fundamental ini memberikan sumber yang utama dan autoritatif dalam perumusan hukum: "Sedangkan dalam kaitannya dengan hadith-hadith Nabi (saw) jelas akan menuntut suatu penelitian yang mendalam terhadap setiap hadith dan latar belakang sejarah saat hadith itu diucapkan oleh Nabi (saw). Dalam hal ini, kewajiban para sarjana yang tergabung dalam kelompok kecil itu hendaknya hanya mempertimbangkan hadith-hadith yang memiliki derajat kemungkinan paling tinggi untuk dikritik secara historis dan teknis. Sedangkan hadith-hadith yang memiliki celah - walaupun sedikit - untuk ditolak kesahihannya hendaklah diabaikan sejak awal " (Muhammad Asad, 1985)

Hadith-hadith ini menyediakan landasan yang jelas dan kuat dalam sistem dan struktur politik yang bakal dibangunkan. Kefahaman-kefahaman ini diambil dari nas-nas hadith yang jelas yang tidak memberi kemungkinan kepada simpang siur penafsiran yang berbelit-belit - dirujuk dari nas yang fundamental, yang bersifat putus dan qat'i. Dan ini dibezakan dengan hadith-hadith yang dimaksudkan umum atau dalam konteks yang khusus - dilihat dari latar belakang dan kondisi sejarahnya (asbab al-wurud): "Betulbetul harus dibedakan secara saksama antara hukum-hukum yang dimaksudkan Rasul (saw) untuk sesuai bagi segala kondisi dan waktu dengan hukum-hukum yang dimaksudkan untuk memecahkan persoalan yang terjadi pada saat-saat tertentu. Hukum-hukum yang termasuk dalam kategori yang disebutkan terakhir itu lazimnya dapat diketahui dari susunan kalimat yang dipergunakan oleh Rasul (saw), atau melalui dukungan penjelasan para sahabat perawi hadith tersebut. Juga, adakalanya ciri seperti itu dapat diperoleh melalui memori-memori yang secara jelas memuat hadith itu di saat ia dikonfirmasi dengan hadith-hadith lain yang berbicara tentang topik yang sama. (Muhammad Asad, 1985)

Ia mengesankan Asad terhadap pertikaian-pertikaian fiqh yang berlarut-larut, yang membelakangi semangat dan sifat asal syariah yang ringan dan mudah (hanifiyah samhah), dimana ritual agama ini telah dipersulit oleh istinbat-istinbat hukum yang kompleks yang membingungkan dari peraturan-peraturan fiqh kepada pemahaman awam: "including the juristic regulations of various jurists (fuqahā) in Sharīah has made Sharīah inaccessible to the understanding of common man. (Muhammad Asad, 2015, pp. 20f).

Kesannya terhadap kesulitan-kesulitan dari pemahaman Islam ini pernah diungkapkannya di hadapan hakim muda di Deh Zangi, Afghanistan yang diimbau 
dalam bukunya The Road The Mecca: "Bagaimana sampai iman Nabi (saw) kalian dan kejernihan serta kesederhanaannya dikubur di dalam reruntuhan spekulasi yang mandul dan ajaran-ajaran yang berbelit-belit?" (Muhammad Asad, 1985)

Tersebab dari ketegangan-ketegangan mazhab yang berpanjangan ini, Asad memilih untuk mendatangkan dalil-dalilnya daripada nas yang fundamental dan qat'i dari alQur'an dan sunnah. Ini membentuk pemahamannya yang asas tentang syariah. Dan pemahaman terhadap sesuatu hadith ini menurutnya harus dibaca serentak dengan kehendak dan maksud al-Qur'an dan hadith-hadith lain yang terkait, bagi mendapatkan gambaran yang menyeluruh terhadap potongan-potongan hadith yang biasanya dibaca secara terpisah: "Kita hendaknya jangan lupa bahwa sebahagian besar hadith-hadith yang diriwayatkan dari Nabi (saw) hanya mengemukakan potongan-potongan kecil ucapan beliau, atau melukiskan peristiwa-peristiwa yang terlepas -yang lebih banyak dipenggal dari kaitan historisnya - dari kedudukan beliau sebagai seorang pemimpin maupun pembuat hukum. Berdasar kenyataan ini, maka suatu perintah yang datang dari Rasulullah (saw) kadang-kadang tidak menampakkan suatu hukum tertentu kecuali bila perintah itu kita baca serentak dengan berbagai hadith lain, atau hadithhadith yang mempunyai kaitan dengan ayat al-Qur'an yang berbicara tentang topik yang sama." (Muhammad Asad, 1985)

\section{Relevansi Hadith di Abad Moden}

Dalam perbincangannya terkait tantangan-tantangan yang dibawa oleh arus pemikiran semasa terutamanya dari peradaban Barat, Asad mempertahankan kerelevenan hadith dalam kesedaran dan pemikiran umat dan perkembangan sejarahnya yang moden. Kefahaman-kefahamannya yang mengesankan dari pengetahuan hadith dimanfaatkan bagi menguraikan kesulitan-kesulitan yang timbul terkait problematika sejarah dan prosesnya. Ia berusaha menghidupkan dan memperbaharui keyakinan terhadap ajaranajarannya. Pemikiran dan kekuatan yang tertanam dalam ajaran-ajaran hadith yang transendental ini mempunyai kesan yang luar biasa dalam menggerakkan kemajuan dalam pemikiran dan budaya dan menggembleng kesedaran terhadap landasan moral dan spiritualnya. Persoalan ini diangkat dalam bukunya, Islam at the Crossroads yang membahaskan dua tema yang krusial terkait permasalahan hadith, i.e. "Hadith dan Sunnah" (bab 6) dan "Jiwa Sunnah" (bab 7). Menurutnya: "Sunnah adalah kunci pengertian kebangkitan Islam lebih dari tiga belas abad yang silam; dan mengapa ia tidak harus menjadi kunci bagi regenerasi kita sekarang? Peninjauan daripada sunnah adalah sama dengan peninjauan kehidupan dan kemajuan Islam. Mengabaikan sunnah adalah sama dengan kekacauan dan kemunduran Islam. Sunnah adalah kerangka besi dari rumah Islam; dan kalau anda lepaskan kerangka itu dari suatu bangunan akan terkejutkah anda apabila gedung itu ambruk seperti rumah-rumah kartu?" (Muhammad Asad, 1983)

Kerelevenan hadith dalam kehidupan umat ini diperlihatkan dalam sejarah moden. Pemikiran hadith ini cukup relevan dan mempunyai kaitan yang mendalam dengan nilai peradaban yang dipertahankan. Keyakinan ini ditunjukkan dalam pembelaan dan kesungguhan Asad mempertahankan ideal dan pengaruh hadith daripada rongrongan 
anasir-anasir yang bobrok yang cuba menggugat keabsahannya sebagai sumber pokok ajaran Islam. Ini dilhamkan oleh kesedaran dan keyakinannya terhadap ketinggian asal usul dan kedudukan hadith yang mendasar sebagai urat tunggang dan poros syariah Beliau memperjuangkan dan menzahirkan penghargaan yang tulen terhadap ajaranajarannya dengan kesungguhan mempertahan dan membela nilai praktikalitasnya dalam ranah dan suasana moden. Kesan-kesan ini dijelaskan dalam pengantarnya kepada Sahih al-Bukhari: The Early Years of Islam (1938): "Keperluan bagi seorang Muslim, untuk mengikuti sunnah Nabi tertegak dengan kukuh dalam al-Qur'an sendiri. Tetapi seseorang dapat bertanya: Mengandaikan bahawa Hadith sepertinya adalah tulen dan boleh dipercayai, adakah kondisi dunia dan masyarakat hari ini membenarkan aplikasi sunnah yang sepenuhnya dalam kehidupan praktis umat Islam, atau adakah aplikasi yang seumpamanya - sebagaimana sebahagian dakwa mengakibatkan kebekuan sosial yang total, dan lantaran itu menjadi halangan yang kekal kepada kemungkinan kerencaman budaya daripada dunia Islam? Terhadap persoalan ini kita punyai jawapan yang definit: Sekiranya, meskipun dengan pengarahan al-Qur'an yang jelas berkait dengan sunnah Nabi, bahawa sunnah tidak dapat dipraktikkan pada masa ini atau masa-masa yang lain, maka satu-satunya kesimpulan yang mungkin diambil adalah perintah al-Qur'an yang bersangkutan, dengan sendirinya, tidak membawa apa-apa makna dan tidak praktikal. Maka bagi seorang Muslim, yang memandang al-Qur'an sebagai Kalam Tuhan, usul ini ternyata tidak dapat diterima. Alhasil, sekiranya kita punyai sebab untuk meyakini bahawa sumber dari mana kita menarik pengetahuan kita tentang sunnah - yakni, ahadith secara historik dapat diandalkan, maka sunnah ini, jika difahami dengan tepat, haruslah dapat dipraktikkan pada setiap ketika dan tidak menjadi halangan kepada kehidupan Muslim."

Kesedaran dan perhatian sejarah yang terbesar terhadap hadith sebenarnya telah dirintis oleh ulama sejak kurun terawal - dalam pencarian dan penyalinan riwayatriwayat yang masif daripada hadith-hadith Nabawi (saw) yang tersebar luas di jajahan Islam. Riwayat-riwayat ini terpencar oleh kedudukan geografis perawi-perawi yang tersebar di wilayah-wilayah Islam berikut penaklukan dan perluasan empayar Islam yang dimulakan sejak zaman Khulafa' al-Rasyidin dalam skala yang luas. Pencarian dan penelitian riwayat ini terus berlanjut dalam perkembangan sejarah dan tradisi pemikiran abad pertengahan. Perkembangan pemikiran hadith dan aliran-alirannya terus berkembang dengan pengaruh luar biasa di benua kecil India. Perkembangan harakat intelek dan pengajian hadith ini digerakkan dengan meluas di Deoband, Kahsmir, Kandahlawi, Saharanpur dan lain-lainnya. Tradisi ilmu dan pengajian kitab turath yang bersandar pada riwayat teks-teks klasik ini telah melahirkan tokoh-tokoh hadith yang penting, seperti Syeikh Abd al-Rahim al-Mubarakfuri, al-Nadwi, Anwar Shah Kashmiri, Muhammad Ilyas al-Kandahlawi, Muhammad Zakariyya al-Kandahlawi, dan sebagainya dengan karya-karya syarah yang meluas ke atas Kutub al-Tis'ah sebagai Tuhfat al-Ahwadhi, 'Awn al-Ma'bud, Lami' al-Darari, Fayd al-Bari, Awjaz al-Masalik, Miftahul Hajah dan sebagainya.

Terkesan dengan dakyat-dakyah Barat dan sebahagian inteligensia Muslim yang terkesan menolak keabsahan hadith, Asad cuba merespon dan menangkis dakwaan liar ini dengan melihat motif sebenar dari dakwaan-dakwaan yang tak berasas ini yang 
bermaksud meruntuhkan tradisi akliah yang dikembangkan dari manhaj yang kritis yang telah dirintis oleh ahli-ahli hadith. Jalan-jalan periwayatan yang dipakai para muhaddithin ini jelas dibuktikan kesahihannya oleh standard yang saintifik yang dipakai kaum modenis dalam pembuktian riwayat-riwayat sejarah secara empirik: "Westernisasi ini adalah sebab yang paling kuat maka hadith-hadith Nabi (saw) kita, dan bersamaan dengan itu struktur sunnah, telah menjadi demikian tidak populer sekarang. Begitu terang sunnah bertentangan dengan ide-ide fundamental yang mendasari peradaban Barat itu sehingga mereka yang terpukau pada ide-ide peradaban Barat itu tidak melihat jalan keluar dari jerat itu kecuali menggambarkan sunnah sebagai satu aspek Islam yang tidak mengena dan oleh karena itu tidak mengikat karena sunnah "berdasar pada tradisi-tradisi yang tidak dapat disandari." (Muhammad Asad, 1983)

Asas pemikiran hadith ini mempunyai pengaruhnya yang tersendiri yang tak tersangkalkan dalam tradisi dan sejarah intelektualnya, Jalan-jalan periwayatan yang diambil dari rampaian-rampaian hadith seperti kutub al-sittah yang terkenal itu terhasil dengan kekuatan dan ketinggian metode riwayah dan dirayah yang jitu. Metode ini dihimbau oleh Asad terkait prinsip al-Bukhari dan Muslim yang menunjukkan ketinggian dan keaslian metode keilmuan dan nilai karyanya yang berpengaruh dan mengesankan: "Malah lebih sulit berbuat demikian karena penyusun-penyusun kumpulan hadith dahulu, terutama Imam Bukhari dan Imam Muslim, telah melakukan segala apa yang mungkin dapat dilakukan manusia untuk menempatkan keaslian setiap hadith pada ujian yang paling keras - ujian yang jauh lebih keras dari yang biasa dilakukan ahli-ahli sejarah Barat terhadap suatu dokumen historik." (Muhammad Asad, 1983)

Dalam keghairahan kita menyongsong abad moden, ia tidak mengurangi keperluan terhadap hadith dan pemaknaan-pemaknaannya yang baru, dalam gelombang dan pergelutan sejarah yang intens, "Mungkin, saya merasa, bahwa kini angkatan yang baru jauh lebih memerlukan risalah itu dibandingkan dengan manusia-manusia pada masa Nabi Besar Muhammad (saw). Mereka itu hidup dalam lingkungan yang jauh lebih bersahaja daripada kita dan oleh karena itu pula masalah-masalah dan kesukaran mereka jauh lebih mudah pemecahannya." (Muhammad Asad, 1985)

\section{Hadith dan Prinsip Ijtihad}

Dalam kupasannya tentang prinsip dan kefahaman asas ilmu hadith, Muhammad Asad memberi tekanan penting terhadap kekuatan tradisi intelektual yang dipertahankan dalam sejarah dan tradisi pemikirannya. Kekuatan akliah ini diilhamkan daripada karya-karya besar ulama yang menekankan aspirasi penting terhadap kekuatan nalar dan ketinggian ijtihad yang menjadi landasan dari penafsiran dan pemahaman teks dan hukum hakam syariat. Asas-asas dan nilai-nilai pemikiran yang mendalam ini dipertahankan dalam tradisi akliah dan sejarah peradabannya. Ia menuntut pembukaan pintu ijtihad dan kebebasan akliah yang meluas dan pengembangannya yang substantif dalam tradisi dan sejarah intelektualnya. Aspirasi ini dijelaskan Asad dalam pengantarnya kepada kitab Sahih al-Bukhari: The Early Years of Islam (1938): 
"Tetapi apakah maksud ayat "sunnah ini, jika difahami dengan tepat"? Adakah interpretasinya - malahan, interpretasi al-Qur'an sendiri - telah ditetapkan kepada kita, secara definitif, pada suatu period yang jauh pada masa lalu? Hal ini malangnya, kelihatan menjadi sikap majoriti yang besar dari umat Islam. Sejak berabad lamanya mereka telah berhenti untuk berfikir secara bebas tentang ajaran Islam dan berpada dengan diri mereka dengan hanya mengulangi ide dan konsep yang dibentuk tidak lewat daripada abad keempat Hijrah, dan sering mencerminkan simpang siur falsafah Neo-Platonik yang menguasai begitu besar pemikiran kebanyakan ulama Islam dari kurun kedua selanjutnya: ide dan konsep yang tidak dalam setiap kes, sejajar dengan tujuan Nabi Terakhir dan para Sahabatnya. Pendeknya, ia adalah kebekuan pemikiran Muslim abad pertengahan tentang ajaran Nabi dan bukan yang disangka "kebekuan sunnah" sepertinya yang tanpa ragu adalah salah satu daripada punca utama kelunturan budaya di dunia Islam. Sudah pasti, tiada yang dapat berpura-pura menyangka karya-karya generasi Muslim terawal dapat dikesampingkan dalam zaman kita; malahan ia adalah suatu kebutuhan bagi kita sebagaimana ia menjadi kebutuhan kepada pendahulu kita. Tetapi adakah kita harus menganggap bahawa semua kemungkinan dari pengetahuan agama telah kering dilacak oleh karya-karya awal itu, dan bahawa tidak ada yang berbaki untuk kita kecuali untuk mengikut mereka secara semberono, tanpa hak untuk merongkai dan menginterpretasinya dalam kerangka yang baru? Jelas, ia tidak mungkin begitu.

Hakikat kebesaran al-Qur'an - dan, selanjutnya, sunnah Nabi - terdiri dalam kenyataan bahawa apabila meningkatnya pengetahuan dunia kita, lebih banyak makna yang baru dan yang sebelumnya tersembunyi terserlah di dalamnya. Ketaqwaan dan komitmen keagamaan umat Islam mungkin lebih rendah pada zaman kita berbanding pada abadabad terawal Islam; tetapi pastinya tidak cara pemahaman kita. Interpretasi yang diberikan kepada ajaran Islam oleh Nabi Terakhir akan selamanya terus mengikat kepada orang Islam; tetapi melangkaui hal ini, dia adalah bebas - malah, dituntut untuk menggunakan daya intelek dan suara dhamirnya sendiri. Hal ini, dan tidak yang lain, adalah sikap pemikir Islam yang besar yang kita sifatkan sebagai imam ("pemimpin"). Mereka tidak pernah berpura-pura sebagai ma'sum; mereka adalah manusia terpelajar yang mengabdi untuk mencari kebenaran, dan mereka arif bahawa tugas berfikir tidak akan pernah lenyap daripada menjadi tugas manusia. Ia adalah tugas kepada Abu Hanifah dan juga kepada Ibn Hazm atau Ibn Rushd; kepada Al-Ghazali dan juga kepada Ibn Taymiyyah atau kepada Shah Waliyullah; dan ia adalah tugas kepada saudara dan kepada saya.

Kebangkitan Islam yang tulen adalah mustahil tanpa pencarian yang intensif terhadap semangatnya yang asli. Kita harus membina lebih lanjut dan tinggi daripada landasan yang diasaskan oleh generasi ulama dan pemikir yang lepas. Kita tidak boleh menerima ide bahawa ajaran Islam akan sesekali menyusut kering dalam segala kedalamannya; dan tiada perkataan seseorang di bawah Nabi dapat sama sekali dipertimbangkan sebagai kata-putus dan muktamad: kesemua kita yang membanting usaha untuk meraih pemahaman yang lebih baik terhadap Kalam Tuhan dan contoh daripada Nabinya adalah pengembara yang mengarah kepada penemuan baru dalam medan spiritual. Dan dalam usaha kita ini kita tidak dapat menemui penolong dan pendamping yang lebih 
baik dari Sahīh al-Bukhārī yang abadi."

\section{Sunnah dan Faham Islam yang Seimbang}

Dalam tradisi pemikiran dan intelektualnya, riwayat-riwayat hadith menunjukkan, menurut Muhammad Asad, penekanan yang jelas terhadap prinsip kesederhanaan yang mengimbangi antara keperluan ruh dan jasad (tubuh kasar), individu dan sosial, dan bukan mengenyampingkan dan menafikan hubungan yang alami dan tak terpisahkan itu sama sekali:

"Oleh karena itu maka tidaklah menunjukkan pengertian yang dalam tentang Islam apabila orang membeda-bedakan perintah-perintah dari Nabi (saw) yang berbicara tentang hal-hal peribadatan dan kerohanian dengan yang berhubungan dengan soalsoal kemasyarakatan dan kehidupan sehari-hari." (Muhammad Asad, 1983)

Kekuatan Islam itu terpancar dari pandangan hidupnya yang seimbang yang memperhatikan soal-soal yang paling halus dan sekecil-kecilnya yang tercakup dalam kehidupan moral dan fisikal manusia. Ia mengambil kira dan memperhitungkan setiap segi dan aspeknya, termasuk hal-hal kehidupan yang dianggap sepele. Menurut Asad "Kode Islam mencakup hidup dalam segala aspeknya, moral dan fisik, individu dan masyarakat, masalah jasad dan pikiran, seks dan ekonomi berdampingan rapat dengan teologi, dan ibadat menduduki tempatnya yang sah dalam ajaran-ajaran Nabi (saw), sedang tak ada sesuatu pun masalah hidup yang tampaknya terlalu remeh untuk ditarik ke dalam orbit permikiran agama - bahkan tak perlu persoalan-persoalan "duniawi" seperti dagang, warisan, hak-hak kekayaan serta pemilik tanah." (Muhammad Asad, 1985)

Aspirasi kehidupan yang seimbang ini didengungkan dalam doktrin dan kepercayaannya yang mengambilkira dan memperhitungkan keperluan-keperluan dan masalah-masalah ini secara keseluruhan, termasuklah kesan-kesannya pada lingkungannya. Pandangan hidup yang asas yang menjadi teras dari ajarannya dalam memenuhi tuntutan-tuntutan dan kebutuhan-kebutuhan manusia yang fundamental. Prinsip yang mempertahankan nilai kesederhanaan dan keseimbangan dalam praktik keagamaan dan yang mengimbangi keperluan ruhaniyah dan badaniyahnya dan maknawiyah dan jasmaniah dengan tuntas: "Bagan sosial yang diutarakannya adalah kesederhanaan yang hanya sejalan dengan keluhuran sejati. Dimulai dari pangkal bahwa manusia adalah makhluk biologis dengan kebutuhan-kebutuhan biologis serta dikondisikan begitu rupa oleh penciptaan, sehingga harus hidup dalam kelompokkelompok agar dapat memuaskan rangkaian kebutuhan fisik, moral, dan intelektual; pendek kata, mereka saling bergantung satu sama lain... (Muhammad Asad, 1985)

\section{Sikap terhadap Sunnah}

Ketundukan kepada sunnah, merupakan prasyarat dalam ketundukan kepada Islam, di mana "Sikap kita terhadap masalah sunnah akan menentukan sikap masa depan kita 
kepada Islam" (Muhammad Asad, 1983, 117). Ini, menurut Asad, menuntut kefahaman dan kesedaran terhadap setiap praktik yang ditunjukkan oleh Nabi (saw) dalam tindak tanduknya sehari-hari. Dalam kesungguhan kita meneladani sikap dan keperibadian beliau itu, dasar dan pandangan hidupnya itu akhirnya menjadi keutamaan dan membawa pada kesedaran Islam yang hakiki: "Dalam segala yang kita lakukan, kita secara permanen didorong untuk memikirkan perbuatan dan perkataan Nabi (saw) yang bersangkutan dengan itu. Dengan demikian maka pribadi manusia terbesar itu terserap dalam-dalam pada kebiasaan kehidupan kita sehari-hari, dan pengaruh spirituilnya menjadi faktor ril yang terus berlangsung dalam kehidupan kita. Secara sadar dan di bawah sadar kita terbimbing untuk mempelajari sikap Nabi (saw) dalam hal ini dan hal itu; kita belajar memandang beliau bukan saja sebagai pembawa pembentangan moral, tetapi juga sebagai penunjuk ke arah kehidupan sempurna." (Muhammad Asad, 1983).

Tujuan-tujuan moral dan spiritualnya ini diperlihatkan dalam praktik-praktik sunnah dan tujuan-tujuannya yang mendasar. Pokok-pokok ajaran yang dibawakannya menggariskan perintah-perintah yang kadangkala tersembunyi dari penanggapan kita. Namun keterbatasan pemahaman dan kesedaran kita terhadap tujuan-tujuan yang strategis ini tidak menafikan pengikutannya secara sedar. Perintah-perintah yang disalurkan dalam sumber-sumber hadith ini menuntut ketundukan dan kepasrahan yang mutlak dan pembelaan terhadap pandangan hidupnya dengan sungguh-sungguh: "Dalam memberi perintah kepada kita untuk melakukan ini dan meninggalkan itu, beliau selalu mempunyai sesuatu tujuan pandangan "strategis" yang menurut pikiran beliau tidak dapat dielakkan untuk kemaslahatan spirituil dan sosial manusia. Kadangkadang tujuan itu nampak jelas dan kadang-kadang, banyak atau sedikit, tersembunyi dari hadapan mata yang kurang terlatih dari kebanyakan manusia; kadang-kadang kita dapat memahami tujuan yang paling dalam dari perintah Nabi (saw) dan kadangkadang hanya tujuan yang dangkal yang sangat langsung. Bagaimanapun halnya, kita terikat untuk mengikuti perintah-perintah Nabi (saw), asal saja keaslian perintah itu telah ditegakkan secara patut." (Muhammad Asad, 1983).

\section{Pemahaman Sunnah}

Kefahaman tentang ideal dan pandangan hidup Islam terletak dalam pemahaman terhadap cita-cita dan tujuan-tujuan pokoknya. Kesedaran ini menghendaki ketundukan kita terhadap perintah-perintah yang terkandung dalam sunnah sebagai prasyarat kepada pemahaman tentang ideal dan pandangan hidup Islam yang sebenar. Dan ini juga turut menghendaki, menurut Muhammad Asad, kefahaman kita terhadap maksud dari perintah-perintah itu sendiri dan hikmah dari pensyariatannya: "Sebaliknya kita harus mempergunakan daya pemikiran itu sebaik mungkin menurut kesanggupan dan pengetahuan kita; kita harus berusaha menemukan arti dan hikmah dan maksud yang terkandung dalam perintah-perintah yang disalurkan Nabi (saw) kepada kita." (Muhammad Asad, 1983)

Ajaran-ajaran Islam ini tidak bersifat dogmatik, sebaliknya adalah hal-hal yang masuk di akal, bukan pengertian-pengertian yang di luar kefahaman dan kepercayaankepercayaan yang membuta sahaja, Pandangan hidupnya jelas diasaskan dengan hujah- 
hujah yang rasional. Premis-premis ini dipertahankan Asad dalam penulisannya seperti The Road to Mecca, menguraikan pemikiran-pemikiran Islam klasik, yang mencerminkan pandangan-pandangan hidup yang progresif dan saintifik: "Tak ada tuntutan yang dipikulkan kepada mereka supaya percaya kepada kerumitan-kerumitan dogma ataupun sesuatu yang tak mungkin dicapai akal; ternyata tak ada dogma yang ditemukan berbentuk bagaimanapun dalam risalah Nabi (saw) (Muhammad Asad, 1985)

Jalan-jalan pemikiran yang rasional ini turut diangkat dalam riwayat-riwayat yang dibawa Asad dalam karyanya The Road to Mecca yang membentangkan periwayatanperiwayatan darihal kepentingan dan ketinggian nilai pemikiran, dan ilmu pengetahuan, seperti ungkapannya: "Nabi (saw) kaum Muslimin sendiri telah menandaskan bahawa mengejar ilmu pengetahuan adalah kewajiban paling suci bagi kaum pria maupun wanita." (Muhammad Asad, 1985).

\section{Sunnah dan Realitas Islam}

Kesedaran Islam dan realitinya ini dibentuk oleh penyerahan dan ketundukan kepada sunnah, di mana "Sikap kita terhadap masalah sunnah akan menentukan sikap masa depan kita kepada Islam" (Muhammad Asad, 1983, 117). Kesedaran ini dicerminkan dari pandangan hidup yang dibawa oleh Nabi (saw), dari perintah-perintah dan ajaranajarannya yang saling mendukung dan menguatkan. Sunnah membentuk asas dari ideal yang diperjuangkan Islam dan membentuk aspirasi dan cita-citanya yang mendasar, "Islam tidak menekankan yang tidak mungkin pada kita tetapi mengarahkan kita bagaimana mengambil manfaat yang sebaik-baiknya dari segala kemungkinankemungkinan kita dalam mencapai wilayah realitas yang lebih tinggi di mana tidak ada penyimpangan dan di mana tidak ada tabrakan antara ide dan perbuatan. Islam bukan salah satu jalan dari jalan-jalan tetapi jalan; dan manusia yang menyampaikan ajaran ini kepada kita bukan hanya salah satu di antara penunjuk-penunjuk jalan, tetapi penunjuk jalan. Mengikuti segala yang dilakukannya dan yang diperintahkannya adalah mengikuti Islam, meninggalkannya berarti meninggalkan realitas Islam." (Muhammad Asad, 1983)

\section{Kitab Sahih al-Bukhari: The Early Years of Islam}

Semasa di India, Muhammad Asad telah merampungkan terjemahan dan syarahan yang dihabiskan selama hampir sepuluh tahun ke atas kitab Sahih. Asal usul sejarah terhasilnya kitab Sahih al-Bukhari: The Early Years of Islam ini pernah dihimbau Asd tatkala merangka dan menyusun dustur dan kaedah dasar bagi negara Islam Pakistan. Usaha yang telah membawanya mempelajari teks-teks hadith secara keseluruhan untuk dirumuskan sebagai suatu dasar dari perlembagaan yang bakal diberlakukan: "Untuk merealisasi tujuan ini (mengedepankan kaidah konsepsional untuk dasar negara Islam Pakistan) saya segera mengambil keputusan untuk menyusun suatu kerangka teoritis bagi suatu dustur Islam berdasarkan pandangan-pandangan politik yang jelas yang diberikan oleh nas-nas al-Qur'anul Karim dan hadith-hadith sahih Rasulullah (saw), 
yang didukung pula oleh pengkajian saya yang memakan waktu cukup lama terhadap al-Qur'an, ilmu hadith dan usul fiqh - suatu upaya pengkajian yang telah pula melahirkan buku terjemahan Inggeris saya untuk Sahih al-Bukhari yang disertai dengan komentar-komentar yang cukup baru." (Muhammad Asad, 1985).

Dalam bukunya, Bukhari, Ghassan Abdul-Jabbar (2007, 131) merumuskan kekuatan terjemahan Asad dan nilai karyanya ini: "Muhammad Asad has done a good translation of the Books in the Sahih which have to do with the Prophet's biography: Sahih alBukhari: The Early Years (New Era publications)."

Elma Ruth Harder, dalam terjemahannya yang meyakinkan ke atas jurnal yang ditulis Muhammad Asad, The Unromantic Orient, turut menyinggung tentang karya terjemahan al-Bukhari ini yang disempurnakan Asad kemudiannya setelah menghabiskan tahuntahun awal pengembaraannya ke Timur Tengah: "During Ramadan in Jerusalem, he vaguely refers to a saying of Prophet Muhammad (saw), peace be upon him: "The physical worship leads to the metaphysical"; later, after visiting a dervish cloister in Istanbul, he writes: "I think of the words of the Prophets, "the discipline of the body, of the limbs, leads to the discipline of the soul". This idea, which he attributes first to "the Prophet" and five months later to "the Prophets" was kept simmering at the conscious level throughout his travels. What role did this nascent interest have in his later years when he devoted almost a decade of his life to the translation of Sahih al-Bukhari, one of the most respected collections of hadith? Did he know in 1923 that he was at the verge of entering Islam?" (Muhammad Asad, 2004).

Kitab Sahīh al-Bukhārī: The Early Years of Islam ini pertama kali dicetak di Srinagar, Kashmir (dua bab) dan Lahore (tiga bab) sepanjang tahun-tahun antara 1935-1938. Ia mengembangkan perbahasan tentang hadith-hadith sahih daripada pandangan dan perspektif Asad yang moden dan kritis. Usaha menterjemah dan mensyarah kitab Sahīh al-Bukhārī ke dalam bahasa Inggeris ini mulanya diilhamkan oleh Muhammad Iqbal, yang mengusulkannya untuk menterjemah teks al-Bukhari ke dalam bahasa Inggeris. Karya ini menjadi usaha pelopor yang terpenting yang digerakkan Asad dalam menterjemah dan mensyarah keseluruhan kitab Sahih al-Bukhari (kira-kira tiga puluh bab), suatu upaya yang belum pernah dibuat oleh mana-mana cendekia Islam pada ketika itu. Komentar yang ekstensif ini adalah penghasilan moden yang signifikan dan pertama kali usaha seumpamanya dipelopori dan diikhtiarkan dalam sejarah dan menjadi sumbangan Asad yang bermakna kepada pertumbuhan dan perkembangan aliran pemikiran dan pengkajian hadith pada abad ke 20. Penerbitannya yang pertama bermula pada tahun 1935 dan jilid pertama yang memuatkan lima bahagian sempat diterbitkan sebelum Perang Dunia Kedua meletus. Kelima-lima bahagian itu yang bakal dituruti oleh tiga puluh lima bahagian lain yang telahpun siap dirampungkan, tergendala cetakannya akibat perang tersebut. Asad berada di bawah tahanan Inggeris di India pada akhir Perang Dunia. Apabila berakhir perang, Asad berhasrat meneruskan usahanya menerbitkan Sahīh al-Bukhārī yang tergendala. Namun, tercetus pula kekacauan antara kaum pada ketika itu yang memuncak kepada pembentukan negara Pakistan. 
Sejak perang berakhir, Asad menetap di daerah Punjab. Dan rusuhan yang meletus pada ketika itu telah memusnahkan segala terjemahan dan huraian Sahīh al-Bukhārī yang dikerjakan selama itu. Para perusuh memecahkan rumah Asad di Punjab dan merampok dan menjarah semuanya yang ditemui termasuk perpustakaan peribadinya dan lembaran naskhah kitab ini, dan mencampaknya ke dalam sungai. Menurut Asad beliau melihat sendiri dengan mata kepalanya bagaimana helaian-helaian manuskripnya terapung di atas arus Sungai Ravi dihanyutkan bersama helaian kitab-kitab Arab yang dicarik dari tinggalan perpustakaannya. Demikianlah lenyapnya usaha yang dikerahkan lebih sepuluh tahun dalam menyusun manuskrip tersebut. Namun Asad tidak berputus asa. Beliau insaf bahawa segala usaha tersebut tidak musnah begitu sahaja sebaliknya adalah persediaan bagi usaha yang lebih agung iaitu terjemahan dan uraian al-Qur'an dalam Bahasa Inggeris berasaskan prinsip bahawa pintu ijtihad tidak akan dan tidak pernah tertutup kepada pencarian intelek manusia. Babak-babak yang mengesankan dari pengalamannya ini dihimbaunya dalam pengantarnya kepada edisi kedua Sahīh alBukhārī: The Early Years of Islam yang dicetak oleh Dar al-Andalus, Gibraltar, pada 1981: "Dikeluarkan dalam lima penggalan bahagian oleh Arafat Publications di Lahore antara Disember 1935 dan Mei 1938, ia adalah bagi mewakili permulaan dari penerbitan yang bertahap daripada karya lengkap saya atas Sahīh al-Bukhārī yang diunjurkan bagi lima atau enam tahun yang berikut... Sebaik saja ia hendak dilanjutkan semula, pada musim panas 1947, kekacauan dan huru-hara agama yang timbul rentetan pemisahan benua kecil India dan pembentukan Pakistan (untuk mana saya sendiri telah bekerja dan perjuangkan sejak 1933) berakibat dalam kehilangan peribadi yang besar pada saya sebagaimana pada begitu ramai yang lain. Sejak berakhirnya perang saya telah menetap di bahagian timur (sekarang India) Punjab; dan ketika meletusnya kemelut pemisahan manuskrip-manuskrip dari hampir tiga-perempat terjemahan beranotasi saya terhadap Sahīh dengan ganasnya musnah. Dengan mata kepala saya sendiri saya melihat carikan dari naskhah manuskrip itu terapung di atas sungai Ravi di tengah kitab-kitab Arab - sisa-sisa dari perpustakaan saya - dan semua macam serpihan; dan dengan helaian kertas-kertas yang malang, terapung itu lenyaplah tanpa dapat ditebus kembali lebih dari sepuluh tahun pembantingan usaha yang dikerahkan." (Muhammad Asad, 2002).

Sebahagian dari manuskrip asal terjemahan Sahīh al-Bukhārī ini telah diterbitkan pada 1938 oleh Arafat Publications, Lahore. Sahīh al-Bukhārī: The Early Years of Islam (Sahīh al-Bukhārī: Tahun-Tahun Terawal Islam) (hh. viii +306$)$ ini mengemukakan rakaman sejarah yang dicatatkan dalam kompilasi hadith yang terpenting, Kitāb al-Jāmi' al-Sahīh oleh Imām al-Bukhārī yang menampilkan detik permulaan wahyu kerasulan, keutamaan para Sahabat Rasūlullāh (saw), dan hari-hari terawal Islam hingga dan termasuk ke suatu detik penentu dalam sejarah Islam, peperangan Badar. Asad telah merancang untuk menterjemahkan keseluruhan Sahīh al-Bukhārī tetapi kebanyakan dari manuskripnya musnah dalam kekacauan yang meletus setelah Perang Dunia Kedua. Ia tidak sia-sia, dalam perkataannya: "sepuluh tahun dihabiskan untuk menganalisis, menterjemah dan menghuraikan kitab Sahīh adalah persediaan yang direncana-Tuhan bagi karya yang sekian lama merupakan mimpi yang membara kepada saya: terjemahan Inggeris yang baru The Message of the Qur'ān...dan intelektual yang membaca karya tersebut dapat mengesan dengan mudah sejauh mana semangat hadith dan dengannya, daya usaha al-Bukhārī yang segar, telah meresap dalam terjemahan 
saya terhadap kalam Ilahi." (Muhammad Asad, 2002, ix). Sahīh al-Bukhārī: The Early Years of Islam ini memberikan lakaran penting tentang manhaj dan kefahaman hadith yang dirakamkan dalam kitab Sahīh al-Bukhārī. Ia menjelaskan idea, serta pandangan hadith yang mendasar, di samping menganalisis ketinggian dan kekuatan riwayat yang dikemukakan dalam kitab Sahīh. Kefahaman ini dizahirkan dalam penyusunan kitab syarah ini yang memberikan kupasan dan huraian yang ekstensif terhadap jalur isnād dan matannya yang menjadi sumbangan yang penting dalam menyingkap mafhum dan keterangan nas-nya dalam pemahaman moden. Dalam menterjemah dan mensyarah kitab Sahīh al-Bukhārī oleh Imām Abū 'Abd Allāh Muhammad ibn Ismā'îl ibn Ibrāhīm ibn al-Mughīrah ibn Bardizbah al-Ju'fĩ al-Bukhārī (194-256/810-870) ini, Asad merujuk pada karya-karya syarah yang muktabar di abad awal dan pertengahan sebagai $A$ 'lam al-Hadith oleh al-Khattabi dan Fath al-Bari oleh Ibn Hajar al-'Asqalani (w. 852/1448), $A$ Kawakib al-Darari (25 Juzuk) oleh Shams al-Din al-Kirmani (w. 786/1384). Menurut Asad, penghasilan kitab syarah dalam bentuk yang baru dan lebih bermaruah adalah mendesak kerana manuskrip-manuskrip klasik yang tersebar sukar dibaca kerana catatannya kacau-balau dan tulisannya bercampur-baur yang menjadikannya sulit untuk diteliti dan dibezakan dengan matan yang asli. Lantaran itu kitab ini dirangka dalam bentuk moden dan sistematik, berbentuk nota kaki (hāshiyah) yang ekstensif. Hal ini memberikan pembahagian yang lebih jelas antara teks [matan hadith] dan syarah nya yang merupakan pembaharuan yang signifikan dalam penulisan syarah di abad moden.

Melihat kepada analisa dan perbahasan moden yang ditampilkan dalam kitab The Early Years of Islam ini, jelaslah kekuatan syarahnya dalam menggarap idea-idea klasik dengan pandangan-pandangan yang kritis dan meyakinkan yang diungkapkannya dalam kupasannya yang signifikan ke atas teks al-Bukhari. Ini mencakupi tinjauantinjauan dan analisisnya tentang tarajjum al-abwāb (tajuk kepala atau keterangan penjelas) al-Bukhari, metode pentarjihan dan penguatan dalil hukum, penghujahan hadith, kekuatan tarjih dan istinbat, penguraiannya terkait asbāb al-wurūd (latar belakang hadith), fiqh al-abwab, maqāsid al-hadīth dan fawā'id al-nas (faedah-faedah yang dikutip daripada nas hadith). Ia menzahirkan kefahaman yang tuntas tentang kaidah-kaidah hukum dengan keluasan analisis dan ketinggian ijtihad. Dengan penterjemahan dan syarahnya yang berkesan dalam mengupas dan menghuraikan nas hadith ini, menzahirkan kesempurnaan penelitiannya terhadap manhaj dan prinsip alBukhari dan keupayaannya menafsir dan memahami idealisme hukum dan maqāsidmaqāsid shar'iyyah yang tercantum di dalamnya.

Kekuatan dan ketinggian manhaj kitab Sahih ini ditinjau secara ringkas dalam pengantarnya pada Sahih al-Bukhari: The Early Years of Islam (1938): "Hal ini tidak bermaksud untuk melakarkan di sini metodologi hadith yang penuh; bait bait di atas hanya sekadar menghuraikan satu daripada alasan terhadap penghormatan luar biasa yang diberikan kepada Kitab al-Jami' as-Sahih oleh Al-Bukhari di seluruh dunia Islam. Penghargaan ini adalah kerana rasa intelektual dan tanggungjawab moral yang tinggi dan persyaratan yang ekstrim ketat di mana penulisnya - yang hidup dalam separuh pertama daripada abad ketiga Hijrah (bersamaan dengan abad kesembilan Masihi) mendekati permasalahan hadith. Standard pemeriksaan dan penelitiannya adalah jauh lebih menyeluruh daripada mana-mana Muhaddith sebelum atau setelahnya; dan 
dengan aman dapat dikatakan bahawa pada hari ini, ia berupaya menjawab tuntutan yang paling rewel daripada kritikan sejarah. Kesedaran kita bahawa Hadith yang dianggap sahih oleh sosok yang paling teliti dari kalangan Muhaddith ini secara historis dapat diandalkan adalah sangat penting kepada masa depan ideologi Islam: kerana di dalam sunnah lah - cara hidup - Nabi Terakhir di mana semangat Islam menemui pengucapannya yang autentik, konkrit; dan ianya melalui ahadith sahajalah dimana sunnah Nabi disampaikan dengan sepenuhnya kepada kita. Dengan perkataan lain, pengetahuan kita tentang hadith adalah kunci yang krusial kepada pemahaman yang sempurna tentang Sunnah dan, dengan demikian, tentang Islam."

\section{Komentar Asad terhadap kitab Sahih}

Dalam perbahasan yang ekstensif pada kitab Bad' al-Wahy dari kitab Sahih al-Bukhari Asad cuba menyorot kemusykilan pada tarjamah bab nya yang dibawakan al-Bukhari dan perkaitannya dengan hadith yang dikeluarkan. Ini diperhalusi dan ditiliknya dengan kupasan yang mendalam:

"Ianya signifikan bahawa Al-Bukhārī menempatkan Hadith (Innama al-a'mal bi alniyyah) ini di permulaan kompilasinya walaupun ia tidak berhubungan dengan subjek dari bab ini, viz., permulaan wahyu. Dia jelas melakukannya kerana menginsafi kenyataan bahawa perkataan Nabi (saw) ini menzahirkan satu dari prinsip etika yang fundamental dari agama dan selain itu, menyentuh masalah yang telah menarik perhatian ahli falsafah sepanjang zaman: masalah Kebebasan Kehendak. Idea tentang Kemahatahuan Tuhan mengandaikan tentang ketentuan-azali ilahi terhadap semua peristiwa, dan konsekuennya, terhadap perbuatan manusia. Pertanyaan yang lama, bagaimana manusia dapat dipertanggungjawabkan atas perbuatannya walaupun ia telah ditakdirkan-terlebih dulu oleh Kehendak Tuhan, dijawab dalam Hadith di atas. Bukan perbuatan nya yang desisif bagi takdir spiritual manusia, tetapi niat nya (niat yang langsung mendahului dan menyertai amal, dan bukan yang telah ditinggalkan atau dirubah pada masa tindakan). Niat manusia adalah ekspresi dari mekanisme psikik yang rumit yang kita panggil jiwa. Dan, walaupun seringkali dipengaruhi oleh pelbagai fungsi dari tubuh, jiwa ini adalah entiti yang bebas, serba lengkap dan berdiri dalam hubungan yang langsung, jika tak dapat diterangkan, dengan Kehendak Ilahi (amr, sebagaimana ia dipanggil dalam al-Qur'an). Dengan jiwa kita sahaja lah di mana kita dapat memahami dan merasai kewujudan Tuhan: dan kita tidak sesekali dapat memahaminya jika kewujudanNya terasing dari kita dalam sifatnya yang mendasar. Kerana hubungan yang akrab dan mulia ini dengan Tuhan jiwa manusia mengambil bahagian dalam prerogatif Ilahi daripada kebebasan yang tiada dalam semua keruwetan material yang kompleks, baik benda atau peristiwa. Justeru, jika kita tidak bebas dalam - dan, kerana itu, dalam pemahaman yang lebih tinggi, tidak bertanggungjawab pada tindakan kita disebabkan karakter nya yang material, diciptakan, - kita bebas dalam niat kita, kerana ianya dari sifat spiritual, yang utama atau kreatif - dan, kerana itu, tanggungjawab dikaitkan dengannya. - Adapun tentang perkataan "niat" ia dapat di sini dinyatakan bahawa dalam keduanya al-Qur'ān dan Hadith ia tidak pernah digunakan dalam pemahaman dari "keinginan" sepintas lalu, tetapi dalam dorongan yang hidup yang dikurniakan dengan sifat kesedaran dan secara langsung berhubung kepada 
peristiwa yang menyusul, apa jua bentuk yang akhir - yang telah-ditakdirkan, dan justeru di luar dari kawalan kehendak bebas kita - dapat akhirnya ambil. Penekanan terhadap "niat" ini pastinya selaras dengan tren yang umum dari ajaran Islam yang diarahkan kepada kesiapsiagaan dalaman dan kesedaran dalam diri manusia." (Muhammad Asad, 2002)

Pada hadith ini ia menguraikan dan memperhitungkan kefahaman yang dimusykilkan berhubung maksud sebenar dari niat, yang menurutnya berhubung langsung dengan Tuhan dari jiwa kita yang mutlak dan bebas yang seyogia diperhatikan dan dinilai Ilahi.

Ungkapan tahannuth (beruzlah, pengabdian yang intens) yang digunakan dalam hadith al-Bukhari juga dimusykilkan dari segi pemakaiannya dalam konteks masyarakat dan pemahaman dasarnya oleh orang-orang Arab waktu itu, yang mungkin dipengaruhi oleh bahasa luar, dan kekhususan lingusitik ini yang diteliti oleh Muhammad Asad:

"Ia agak sukar untuk dengan tepat menterjemahkan istilah tahannuth yang digunakan dalam teks Arab. Ia terdapat dalam dua bacaan, yang lain adalah tahannuf. Tahannuth berasal dari hanth, dan bermaksud "menjauhi dosa." Tetapi sebagaimana ini tidak sama sekali mengikuti dengan pernyataan berikutnya "yakni, ibadah," kita harus menerima bacaan kedua tahannuf sebagai tepat: dan ia adalah, malah, kekhasan linguistik yang terkenal dalam masyarakat Arab di mana dalam ucapan mereka, mereka sering merubah konsonan $f$ kepada kepada th. Sekarang, perkataan tahannuf, bukan berasal dari bahasa Arab, tetapi kemungkinan diambil dari bahasa Canaanite-Aramaic hanpa yang secara literal bermaksud "seseorang yang berpaling." Dalam bahasa Syriac ia secara menonjol digunakan untuk menggambarkan seorang yang berpaling dari agamanya, seorang pemberontak; kerana itu Maharaja Romawi Julian yang Murtad yang meninggalkan agama Kristian dan bertukar kepada agama Romawi kuno dipanggil, dalam manuskrip Syria-Kristian, Yulyāna hanpā; istilah yang sama sering diterapkan kepada Manichaeans dan Sabaeans, kemungkinan disebabkan kenyataan bahawa agama mereka mengandungi unsur-unsur Kristian tanpa sepenuhnya menganut doktrin dari Gereja Kristian. Ketika orang-orang Arab, dalam zaman pra-Islam, menyesuaikan perkataan ini kepada bahasa mereka, mereka menggunakannya dalam pemahaman yang asli dari "berpaling", yakni, dari penyembahan berhala, dan, kemudiannya, dari setiap jenis keduniaan. Dari situ tahannuf menunjukkan peribadatan yang ghairah (umumnya terdiri dari berjaga malam dan sembahyang) dari pencari-Tuhan yang bertauhid yang, kerana itu, dipanggil hunafä' (tunggal haniff) - panggilan yang menjadi akrab kepada umat Islam disebabkan perkaitannya, dalam al-Qur'ān, dengan nama Ibrahim. Disana ia hampir sinonim dengan “Unitarian.” (Muhammad Asad, 2002).

Kemusykilan pada ungkapan iqra' dalam hadith juga diperhalusi dalam syarahnya, yang lebih cenderung pada maksud "baca" ketimbang "sebut": "Dalam perkataan "Bacalah!" yang membuka wahyu pertama kepada Muhammad (saw) panggilan kepada Kenabian yang Sempurna ini telah sepenuhnya diekspresikan. Syariat Tuhan, Kebenaran yang Abadi di sebalik benda-benda yang terlihat, disingkapkan di depannya, menunggu untuk difahami olehnya dalam maknanya yang terdalam. Justeru ia akan keliru untuk menterjemahkan iqrā' di sini sebagai "sebutkan" - walaupun bahasa Arab pastinya membenarkannya - kerana penyebutan menyiratkan penyampaian kepada khalayak 
dari sesuatu yang dihafal dalam ingatan - dan pada saat yang pertama dari kemunculan malaikat masih belum ada sesuatu dalam ingatan Nabi (saw), dan tiada khayalak. Sebaliknya, "membaca" menyiratkan pengikutan dengan sedar dan asimilasi mental terhadap perkataan atau idea dari sumber luaran: dan ini, tanpa syak, adalah benda yang dituntut dari Nabi (saw). Pada mulanya, dia berilusi bahawa dia diperintah untuk membaca naskhah yang sebenar, dan ini, dia tahu, dia tidak sanggup kerana dia buta huruf. Tetapi ketika malaikat mengakhiri Wahyu ini, Nabi (saw) mula faham, dengan pencerahan yang mendadak, bahawa dia diperintahkan untuk menerima pesan spiritual dari Yang Maha Agung; dan besarnya tugas ini dengan semua implikasinya dari tanggungjawab dan pengorbanan-diri memberatinya dan memenuhinya dengan ketakutan." (Muhammad Asad, 2002, 25)

\section{Kesimpulan}

Dari analisis ringkas tentang doktrin dan pemahaman hadith yang dibawa Muhammad Asad jelaslah kekuatannya yang merangkul prinsip-prinsip dan kaedah-kaedah yang krusial dalam pemikiran hadith. Ia memberi asas yang penting dalam analisis-analisis sejarah yang mendalam yang dikemukakannya tentang riwayat-riwayat hadith dan pengaruhnya ke atas aliran-aliran mazhab yang berkembang dalam tradisi pemikiran dan intelektual Islam. Ini dizahirkan secara prinsipal dalam perbahasannya tentang pengaruh aliran kaum teolog, kalam dan sufi terhadap pemahaman hadith dalam Kitab al-Iman (The Book of Faith) dalam kitab Sahih al-Bukhari The Early Years of Islam ini yang menyentuh tentang permasalahan-permasalahan terkait dengan kemusykilankemusykilan akidah dari hadith-hadith al-Iman dan pengaruhnya terhadap kepercayaan dan iktikad salaf. Dalam menganalisis kefahaman-kefahaman ini ia cuba menghuraikannya berdasar pada prinsip yang digariskan al-Bukhari dalam tarajjum alabwab-nya yang memperlihatkan penafsiran dan pendirian al-Bukhari terkait persoalan-persoalan yang dimusykilkan dari hadith-hadith yang dikeluarkan. Analisisnya terhadap hadith-hadith Sahih dan penyorotannya terhadap permasalahanpermasalahan terkait ini menjelaskan prinsip yang penting dan klasik yang dibawanya dalam mengembangkan pemikiran-pemikiran dan pemahaman moden dan progresif terhadap matan al-hadith.

\section{Daftar Pustaka}

Ghassan Abdul-Jabbar. (2007). Bukhari. London, New York: I.B. Tauris.

Muhammad Asad. (1983). Islam di Simpang Jalan. M. Hashem (pent.), cet. 3. Bandung: Pustaka.

Muhammad Asad. (1985). Sebuah Kajian tentang Sistem Pemerintahan Islam. Afif 
Mohammad (pent.), Ammar Haryono (pnyt.). Diterjemahkan dari Minhaj al-Islam fi alHukm. Jakarta: Pustaka Mizan.

Muhammad Asad. (1985). Jalan ke Makkah. Fuad Hashem (pent.). Jakarta: Pustaka Mizan.

Muhammad Asad. (1999). Islam at the Crossroads. Kuala Lumpur: Other Press.

Muhammad Asad. (2003). The Message of the Qur'an. London: The Book Foundation.

Muhammad Asad. (2003). "Social and Cultural Realities of the Sunnah", dalam P.K. Koya (ed.), Hadith and Sunnah: Ideals and Realities, pp. 233-250. Kuala Lumpur: Islamic Book Trust.

Muhammad Asad. (2004). The Unromantic Orient. Elma Ruth Harder (pent.). Petaling Jaya: IBT.

Muhammad Asad. (2013). Sahīh al-Bukhārī: The Early Years of Islam. Kuala Lumpur: Islamic Book Trust.

Muhammad Asad. (2015). This Law of Ours and Other Essays. Kuala Lumpur: Islamic Book Trust.

Muhammad Arshad. (2016). "Muhammad Asad: Twenty-Six Unpublished Letters", Islamic Science, Vol. 14 (Summer) No. 1, 25- 66. 